\title{
10 T. Unraveling the Shift to the Entrepreneurial Economy
}

D.B. Audretsch'

A.R. Thurik ${ }^{2}$

' Institute for Development Strategies, Indiana University;

2 Erasmus School of Economics, Erasmus University Rotterdam, Tinbergen Institute, and EIM/Panteia, Zoetermeer. 


\section{Tinbergen Institute}

The Tinbergen Institute is the institute for economic research of the Erasmus Universiteit Rotterdam, Universiteit van Amsterdam, and Vrije Universiteit Amsterdam.

Tinbergen Institute Amsterdam

Roetersstraat 31

1018 WB Amsterdam

The Netherlands

Tel.: +31(0)205513500

Fax: $+31(0) 205513555$

Tinbergen Institute Rotterdam

Burg. Oudlaan 50

3062 PA Rotterdam

The Netherlands

Tel.: + $31(0) 104088900$

Fax: $+31(0) 104089031$

Most TI discussion papers can be downloaded at http://www.tinbergen.nl. 


\title{
Unraveling the Shift to the Entrepreneurial Economy
}

\section{D.B. Audretsch and A.R. Thurik}

\author{
Institute for Development Strategies, Indiana University, daudrets@indiana.edu \\ Erasmus University Rotterdam and EIM/Panteia, Zoetermeer, thurik@ese.eur.nl
}

\begin{abstract}
A recent literature has emerged providing compelling evidence that a major shift in the organization of the developed economies has been taking place: away from what has been characterized as the managed economy towards the entrepreneurial economy. In particular, the empirical evidence provides consistent support that (1) the role of entrepreneurship has significantly increased, and (2) a positive relationship exists between entrepreneurial activity and economic performance. However, the factors underlying this observed shift have not been identified in a systematic manner. The purpose of this paper is to suggest some of the factors leading to this shift and implications for public policy. In particular, we find that a fundamental catalyst underlying the shift from the managed to the entrepreneurial economy involved the role of technological change. However, we also find that it was not just technological change but rather involved a number of supporting factors, ranging from the demise of the communist system, increased globalization, new competition for multinational firms and higher levels of prosperity. Recognition of the causes of the shift from the managed to the entrepreneurial economy suggests a rethinking of the public policy approach. Rather than the focus of directly and exclusively on promoting startups and SMEs, it may be that the current approach to entrepreneurship policy is misguided. The priority should not be on entrepreneurship policy but rather a more pervasive and encompassing approach, policy consistent with an entrepreneurial economy.
\end{abstract}

First version: August 2010

Current version: April 2011

Document: Unraveling dba art v21

SaveDate: 4/2/2011 1:40

Acknowledgement: we would like to thank Shazhad Ansari, Joern Block, Isabel Grilo, Matthijs van der Loos, Erik Stam, André van Stel, Erik Swets, Linda Vreeswijk, Sander Wennekers, Vitalija Gaucaite and Haibo Zhou for assistance and comments. In particular, we thank José Louis González Pernía for his assistance finding sources for our section on the demise of the Soviet system. The writing of this manuscript benefited from short visits of Roy Thurik to EM-Lyon, IDS Indiana University and GSCMMontpellier Business School. Early versions have been read in Brussels, Tylösand, Leuven, Zoetermeer, Capelle, The Hague, Lyon, Woerden, Reus, Rotterdam, Caen, Nieuwerkerk, Cartagena, Bilbao, Caceres, Covilhã, Berlin, London and Cali. This paper has been written in cooperation with the research program SCALES, carried out by EIM and financed by the Dutch Ministry of Economic Affairs. 


\section{Unraveling the Shift to the Entrepreneurial Economy}

\section{Introduction}

While considerable celebration occurred subsequent to the fall of the Berlin Wall in 1989, one of the bolder claims suggested that "the end of history" (Fukuyama, 1989 and 1992) had been reached, in that the great competition among economic systems characterizing the Postworld War II period had finally been resolved. According to Fukuyama (1992), "What we may be witnessing is not just the end of the Cold War, or the passing of a particular period of postwar history, but the end of history as such: that is, the end point of mankind's ideological evolution and the universalization of western liberal democracy as the final form of human government.”

Fukuyama's characterization of an evolution from competing political and economic systems to a convergence towards a singular political and economic system corresponded with the thesis posed by Audretsch and Thurik (2000 and 2001) that the post-war era characterized by the managed economy has been replaced by a contemporary entrepreneurial economy. ${ }^{1}$ The managed economy is defined as an economy where economic performance is positively related to firm size, scale economies and routinized production and innovation. By contrast, the entrepreneurial economy is defined as an economy where economic performance is related to distributed innovation and the emergence and growth of innovative ventures.

While the managed economy was characterized by a divergence of institutional and policy approaches to the underlying economic problem of that era, maximizing the efficiency and productivity of large scale production while minimizing any social and political negative externalities from a concentration of economic power, the entrepreneurial economy is characterized by a convergence of institutional and policy approaches designed to facilitate the creation and commercialization of knowledge through entrepreneurial activity.

A recent literature suggests that the managed economy was being replaced by the entrepreneurial economy, not just in a few regions, such as Silicon Valley and Research Triangle in North Carolina, or a single country, such as the United States, but rather was diffusing throughout all developed countries (for instance, Baumol, 2002; Florida, 2002; Wennekers, Van Stel, Thurik and Reynolds, 2005; Baumol, Litan and Schramm, 2007; Audretsch, 2007b; The Economist, 2010). This literature helped triggering an awakening in policy debates to promote entrepreneurship through "entrepreneurship policy". Governments, spanning local, city, regional, national and even supranational, such as the EU, began a vigorous and targeted effort to spur the startup of new firms and the growth and survival subsequent to start up.

While Audretsch and Thurik (2000 and 2001) identify how the manifestations and characteristics of the managed economy differ from those characterizing the entrepreneurial economy, the exact reasons triggering the shift from the managed to the entrepreneurial economy remain unexplored and unarticulated (Baumol, Litan and Schramm, 2007). Thus, the purpose of the present paper is to explain why the shift from the managed to the entrepreneurial economy has taken place.

\footnotetext{
${ }^{1}$ After writing our 2000 and 2001 articles we discovered that the first to use the term entrepreneurial economy - although not in our broad sense - has been Peter Drucker in 1985 in his Innovation and Entrepreneurship. A visionary article in The Economist on December 25, 1976 called "The coming entrepreneurial revolution: a survey" predicts the end of the corporation management system - which is roughly our managed economy. It will not be replaced by state capitalism - the then avant garde European view - but with a new system in which scale and organization loose their dominance and persons and new technologies take over.
} 
The answer seems to be involved with technological change. However, as we emphasize, the impact of technological change in leading to a shift from the managed to the entrepreneurial economy has been imbedded in a myriad of supporting factors, spanning from the demise of the communist system, increased globalization, new competition for multinational firms, their strategic responses and higher levels of prosperity.

By technological change we mean the second ICT wave (the miniaturization and communication wave and not the mainframe effect). In particular, the arrival of Intel's 80486 microprocessor together with Microsoft's Windows 3 operating system around 1989 meant a breakthrough in the already fast moving ICT revolution. The rise of the number of firms and the decline in firm size predates this ICT revolution (Blau, 1987; Carlsson, Acs, Audretsch and Braunerhjelm, 2009; Wennekers, Carree, Van Stel and Thurik, 2010). This is not just the effect of capital deepening but also reflects the post-Chandlerian world where new organizational forms play a role such as flexible specialization (Piore and Sabel, 1984), flexible multi-product firms (Milgrom and Roberts, 1990), vertical disintegration (Langlois, 2002) and 'between market and hierarchy' relations (Langlois, 2003). Our approach is more (neo)-Schumpeterian in that there is a relentless drive for innovation and hence opportunities and learning (Nooteboom, 2000; Baumol, 2002; Sabel and Zeitlin, 2004). Hence, it is the entrepreneurial effect rather than the firm size effect we wish to explain. ${ }^{2}$

The impact of technological change and its many moderators on entrepreneurship is so complex and pervasive that the policy implications are beyond those of just creating entrepreneurship policy next to the existing avenues of policies. The ascendance of entrepreneurship policy, with its focus on promoting startups and SMEs (small and mediumsized enterprises), was certainly consistent with the characterization that the entrepreneurial economy had superseded the managed economy. ${ }^{3}$ However, identification of the factors underlying why this shift actually occurred leads to a rethinking of the policy conclusion. Rather than a narrow focus on promoting startups and SMEs, the appropriate response of public policy should be to re-think the policy approach in a broad and pervasive sense, so that the focus is not on developing entrepreneurship policy, but rather policy for the entrepreneurial economy.

In short, the present paper attempts to combine existing arguments and insights as to why the regime switch from the managed economy to the entrepreneurial economy happened in an essay style manner. We will present no new empirical evidence that there has been a switch nor will we synthesize its literature. Our emphasis is on the model why it happened given that it happened around the late eighties/early nineties of the last century.

\section{Linking ICT to the organization of the economy}

An important catalyst for the shift from the managed to the entrepreneurial economy is technological change, and in particular the emergence of information and communication technologies (ICT). There are numerous reasons why the advent of the ICT revolution had such an impact on structural change in developed industrialized countries. It is the purpose of the present contribution to explicitly identify those factors associated with ICT which are influencing the emergence of the entrepreneurial economy. By and large, the ICT revolution led to new restrictions and opportunities for multinational corporations. These corporations which provided the essence of the managed economy had to review their business models. This led to

\footnotetext{
${ }^{2}$ The pervasiveness of this new flexible economy is witnessed by the many names it has been given: 'post-industrial economy', 'Post-Fordist economy', 'information economy', 'innovation economy', 'knowledge economy', 'post-materialist economy', 'information economy', 'network economy', 'digital economy’, 'service economy’, 'weightless economy', 'e-economy’, etc. See also Baumol, Litan and Schramm, 2007.

${ }^{3}$ Various versions of the many channels through which government intervention can take place are presented in Audretsch, Thurik, Verheul and Wennekers (2002), Audretsch, Grilo and Thurik (2007) and Thurik (2009).
} 
an emphasis on knowledge based economic activities (Audretsch, 1995) as well on organizational techniques based on outsourcing and even off-shoring (Friedman, 2005). Hence, the comparative advantage of high-wage countries also moved towards knowledge-based economic activity and sophisticated forms of organization.

Already before the fall of the Berlin Wall and the ensuing wave of globalization, the conventional wisdom predicted that small firms would wither away. In particular, during the early 'main frame' phase of the ICT revolution it was predicted that this technology would be something of a final blow for small scale operations (Audretsch, 2007b). Small firms were viewed as something Western countries needed to ensure decentralized decision making, obtained at the unfortunate cost of efficiency. Many stylized facts were discovered about the role of small firms in the post-war managed economies of North America and Western Europe. For instance: Small firms are generally less efficient than their larger counterparts. Studies from the United States in the 1960s and 1970s revealed that small businesses produced at lower levels of efficiency than larger firms (Weiss, 1976 and Pratten, 1971). Small firms are characterized by lower levels of employee compensation. Empirical evidence from both North America and Europe found a systematic and positive relationship between employee compensation and firm size (Brown, Hamilton and Medoff, 1990; Brown and Medoff, 1989). Small firms are only marginally involved in innovative activity. Based on R\&D measures, small businesses accounted for only a small amount of innovative activity (Chandler, 1990; Scherer, 1991; Acs and Audretsch, 1990; Audretsch, 1995). The relative importance of small firms is declining over time in both North America and Europe (Scherer, 1991). The long decline of self-employment since there has been economic activity becomes more and better documented (Wennekers, Carree, Van Stel and Thurik, 2010).

Figure 1 summarizes the links identified and explored in this paper. The starting part for this shift was the external shock of the advent of ICT, which not only triggered numerous intermediate changes but ultimately led to the entrepreneurial economy with its emphasis on the role of startups and SMEs. The numbers associated with the arrows refer to the corresponding sections in this paper addressing each link in explaining the shift from the managed to the entrepreneurial economy.

As Figure 1 shows, there is more than just the strategic response of multinational corporations to global competition reviewing their business models to explain the pervasive nature of the structural change of the managed towards the entrepreneurial economy. First, ICT can be considered a general purpose technology (Helpman, 1998). Technology introductions of that kind have a deep impact on the organization of industry. This is the subject of section two of the present paper. Second, the shifting patterns of international specialization caused by the abundant supply of cheap labor of the new players was not just the result of the distance destroying capacity of ICT but also of the political opportunity and determination to deregulate world trade (Thurow, 2002). Section three deals with the character and the drivers of globalization as it occurred during the last two decades. Third, the influence of ICT on the demise of the communist system is the subject of section four. Fourth, the typical character of the globalization wave created new restrictions and opportunities not only for multinational corporations but also for the developed industrialized countries which generated these corporations. Section five deals with the consequences of globalization as it manifested itself during the last two decades. Fifth, making and using knowledge is the most important consequence of the fading of physical capital as the competitive advantage of developed industrialized economies (Archibugi and Lundvall, 2001; Foray, 2004). Knowledge capital is not just based upon scientific and technological understanding but also a wider comprehension and awareness of novelty, originality, creativity and ideas (Nooteboom and Stam, 2008). Its use depends on its propensity to spill over among people, organizations, regions and industries. Spillovers do not happen just like that. Discrepancies in levels of knowledge among economic 
agents result from high uncertainties, considerable asymmetries and substantial costs of transaction. This also applies for a more vertical spillover of knowledge from scholarly content to a potential commercial application. Also, there may be inconsistency between a new idea and the core competence of the incumbent corporation where it started to develop. This jam is termed the knowledge filter (Audretsch and Lehmann, 2005; Audretsch and Keilbach, 2007; 2008). The role of knowledge and the importance of its spillover as well as the role of startups and SMEs unjamming the knowledge filter are dealt with in section six. This role complements the roles of entrepreneurship mentioned in section two. Sixth, a final role of startups and SMEs results from the massive spurt in economic growth resulting from the introduction of ICT, the expansion of the participating part of the global economy (i.e., the absorption of the labor reserve of the emerging economies) and the reallocation of economic activities. The ensuing unprecedented high levels of economic prosperity in the formerly industrialized countries led to demand characteristics favorable to entrepreneurial organizational structure. This is the subject of section seven. Finally, the last section provides a summary and conclusion, along with implications for public policy. The traditional approach that constitutes entrepreneurship policy has a primary and exclusive focus on promoting startups and SMEs. However, considering the forces underlying the shift away from the managed economy and the emergence of the entrepreneurial economy suggests that a considerably broader approach may be more effective, and in particular, one that re-orients all institutions towards promoting entrepreneurial behavior (Stam and Nooteboom, 2011). Rather than just focus on specific instruments to promote startups or high-growth firms, this new role calls for a fundamental all encompassing re-thinking of public policy that spans all dimensions of the economy, which is termed not as entrepreneurial policy but rather policy for the entrepreneurial economy. 
Figure 1 Linking ICT to the organization of the economy (numbers refer to the section numbers of this paper).

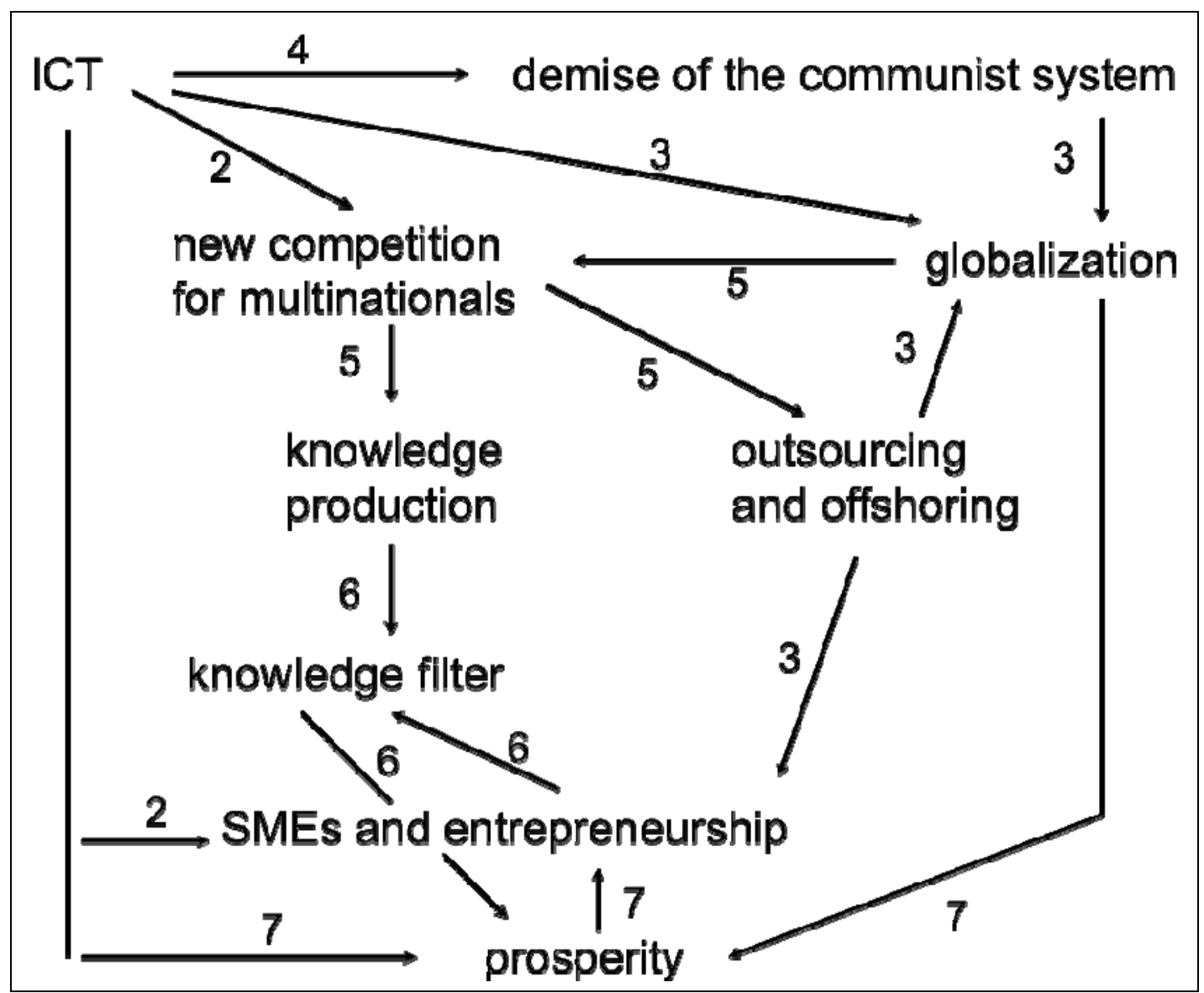

\section{Technological change and entrepreneurship}

While Karl Marx, in his analysis of technological determinism, may not have been the first scholar, he certainly was among the most prominent to make a link between technology and institutions, broadly considered. The impact of technological change as characterized by the advent of ICT on organizational structure has shifted the competitive advantage away from larger scale organizations to smaller scale organizations (Piore and Sabel, 1984; Brock and Evans, 1989; Nooteboom, 1999 and 2000). ${ }^{4}$ This is depicted by arrows numbered 2 in Figure 1. There are a number of reasons why ICT has made entrepreneurship in the form of startups and SMEs more competitive. The first reason involves the role of entrepreneurial firms and the emergence of new technologies. Any economic regime switch based upon a radical new technology is accompanied by the arrival of numerous small firms. Klepper (1996), for example has documented that in the early stages of the life cycle of industries, small and new firms tend

\footnotetext{
${ }^{4}$ As mentioned before, by technological change we mean the second ICT wave (the miniaturization and communication wave brought about by firms like Intel and Microsoft). This second wave meant a spurt in the already fast moving ICT revolution. The rise of the number of firms/decline in firm size predates this second ICT revolution and reflects the post-Chandlerian world where new organizational forms with higher levels of flexibility were made possible and demanded.
} 
to play an important role. See also Jovanovic and Rousseau (2005) dealing with examples from the advent of the electricity and IT industries and their effect on the US economy. This is because the new technology, which creates new markets by definition, also destroys incumbent market positions and the entry barriers typical for the older technology and its market (Henderson and Clarke, 1990). ${ }^{5}$ Hence, entry into new industries in the initial stages of the life cycle is made easy (Tirole, 1989). In addition, in the early stages of new markets price elasticity is low because of the novelty of the product (Parker, 1992). The small firm of the typical entrant has no disadvantage because there is no competitive pressure to fight the battle of scale economies.

However, while the life cycle model explains the relative competitive advantage of small and new firms in new industries triggered by new technologies, there are two additional reasons specific to ICT which have reduced the competitive advantage of large firms. First, ICT tools and open access to the Internet created a world wide platform for relations between firms irrespective of their size. The marginal costs of communication dropped (Shapiro and Varian, 1999; Brousseau and Curien, 2006). Small firms in particular need these relationships to compensate for their narrow set of competencies and limited scope for investments in human, social and financial capital (Nooteboom, 1994). The second has to do with the scale effects in transaction costs (Nooteboom, 1993) when firms engage in deals, try to do so or want to monitor them. Transaction costs are higher for small firms when compared to large firms. This has to do with the fixed costs involved with setting up information systems for search, evaluation, control and enforcement. These fixed costs consist of necessary hardware, software and mastering their use. The arrival of the ICT tools which are generally cheap, small and easy to use together with the practically free access to the Internet has almost eliminated the fixed cost part in the transaction costs of any deal. The fixed costs part of communications dropped.

The second factor involves the increased importance of knowledge and innovation as the source of competitiveness in global markets. As Thurow (2002, p. 25) observes, "The world is moving from an industrial era based upon natural resources into a knowledge-based era based upon skills, education, and research and development.” In the knowledge intensive economy there is more need for the exploration side of doing business as well as the 'software side' (human and knowledge capital) (Audretsch and Thurik, 2001)). A well-known conflict in the strategic renewal of firms is whether to engage in exploration or exploitation activities (March, 1991). This difficult choice between exploration and exploitation is made easier because, as we explained above, firms in high cost locations hardly have a competitive advantage when it comes to exploiting scale economies by fine tuning the production process. This fine tuning is a process of extreme focus eliminating every redundant part in the production process using division of labor and mechanized tasks and the smooth interplay of the labor and machines involved (Chandler, 1990; Teece, 1993). Once an optimum given a certain product is reached little prevents the forces of the globalized world to move this optimum to wherever labor costs are lowest. Exploration is an entirely different activity requiring openness, flexibility and experimentation instead of focus and elimination (Audretsch and Thurik, 2001). It thrives in environments where variety and cooperation can be made useful to break the knowledge filter (Carlsson, Acs, Audretsch and Braunerhjelm, 2009). These are typically 'industrial district' like and 'open source' oriented environments with many small firms and much turbulence (Breschi and Malerba. 2005; Chesbrough, Vanhaverbeke and West, 2006). An additional effect is removal of one of the major scale effects in the exploitation stage of the product life cycle: easy to use and cheap ICT tools in part destroy the fruits of large scale (Langlois, 2003; Carlsson, Acs, Audretsch and Braunerhjelm, 2009). The above-mentioned drop in the fixed part of the transaction costs threatens scale effects in distribution. Remains the reputation effect which

\footnotetext{
${ }^{5}$ There is also a literature on the advantages that large incumbent firms have over their new small counterparts (Chandler, 1990; Teece, 1993). See Tripsas (1997) for an analysis of the two perspectives. See also Ansari and Klop (2008).
} 
indeed protects many incumbent businesses, for instance in the fashion or life style industries (Barney, 1991; Dyer and Sinh, 1998). Another cause of the decreased importance of the exploitation stage of the product life cycle is the increased wealth of the global consumer. She can afford to behave whimsically and individualistically so that the exploitation period of any given product decreases when compared to the exploration stage (Day, 1981; Lee, 2002). Finally, the discrimination between the exploitation and exploration sides of doing business decreases. This is the world of prototypes, beta versions, simulations etc. This merger between the exploitation and exploration stages is necessary because of demand pressures (Golder and Tellis, 2004) but also made possible by the introduction of numerical controlled machines, i.e., robots (Acs, Audretsch and Carlsson, 1991). Computer aided design and other forms of standardized interfaces facilitate vertical cooperation and the speed with which products can be brought to the market (Langlois, 2002).

The fine tuning of the production process involves both software and hardware. Software involves human and knowledge capital while hardware includes physical capital. In the knowledge intense economy the bottleneck is software rather than hardware since globalization together with the whimsical and individualistic consumer makes investments in inflexible hardware dangerous (McLaren, 2000). Rejuvenation of labor by training or replacement and improvement of knowledge by joining loose networks of businesses or cooperation with research institutes is cheaper than rebuilding factories and plants (Stam, 2007). By and large, the shape of factories in the service industry differs from that in manufacturing where investments in hardware are closely connected to a specific product. In the services hardware takes the shape of buildings and offices which can be used for different and changing portfolios of software, i.e., of labor and knowledge. This is one of the reasons why Western countries have not lost their competitive advantage in the service industries. The higher orientation towards software creates more room for SMEs in many industries.

Traditionally, knowledge disclosure or 'leakage' is the most important impediment for businesses to cooperate. Leakage is the unwanted spillover of knowledge or competencies which cannot be protected by patents, copyrights, etc and which is detrimental to the specific capabilities of a firm (Porter and Liebeskind, 1996; L'Huillery, 2006). A firm's competitive position can be negatively effected by leakage if the knowledge or competencies spill over beyond the boundaries of a specific cooperative effort and its partners towards potential competitors (Hamel, 1991; Nooteboom, 2002). Of course, a solution is the contracting and maintenance of exclusivity. This again has several disadvantages. First, many modern forms of cooperation have ill defined goals and means by definition since they aim for novelty (Baumol, 2002). Second, the transaction costs involved in setting up, monitoring and enforcing exclusivity contracts can be high because of their complexity and uncertainty (Nooteboom, 1993). Lastly, exclusivity contracts limit the spontaneity of the process of learning that is essential in the process of joint learning (Nooteboom, 2000). 'Leakage' is less of a problem in the globalized economy with its fast changing consumer tastes and its fast changing technological opportunities. First, these fast changes limit the time for competitors to absorb the potential fruits of a third party cooperative effort. By the time it understands, imitates, implements and commercializes the original cooperative efforts the originator already works on further developments and improvements (Cohen and Levinthal, 1989; Zahra and George, 2002). Second, as described above, more and more competitive advantage is the potential to combine processes of exploitation and exploration (Ireland and Webb, 2007). This combination is a way of rejuvenation which is deeply engrained in a firm's organizational culture and cannot be easily imitated. In short, an essential part of the competitive advantage of modern firms is their ability to bring about change in products and technology and less to understand the virtues of existing products and technologies (Baumol, 2002; Audretsch, 2007b). Protection of what already exits 
as well as 'leakage' of its deeper characteristics has become less important. This protection was more difficult for SMEs.

Thus, there were multiple avenues rendering startups and SMEs more competitive than their larger counterparts as a result of the ICT revolution. While we examine the impact of globalization on the relative competitiveness of startups and SMEs in the next section, an important conclusion of this section is that the ICT revolution generated competitive advantages to SMEs.

\section{Globalization}

While the shift from the managed to the entrepreneurial economy is partly attributable to technological change, and in particular the advent of ICT, this is not the sole factor or reason. A second factor involves the process of globalization (Audretsch and Sanders, 2007). Like all grand concepts, a definition for globalization is elusive and elicits criticism. The term is generally connected to the (rapid increase of) free movement of goods, capital, people and ideas around the globe. ${ }^{6}$ That domestic economies are globalizing is a cliché makes it no less true. In fact, the shift in economic activity from a local or national sphere to an international or global orientation ranks among the most vigorous changes shaping the current economic landscape (Dreher, Gaston and Martens, 2008). The present section deals with the character and the drivers of this shift which hit the world economy during the last two decades (arrows numbered 3 in Figure 1). Globalization did not happen exogenously or independently with respect to the important factor identified in the previous section as triggering the shift from the managed to the entrepreneurial economy, ICT. Rather, ICT itself has facilitated the emergence of contemporary globalization (Cairncross, 1997; Castells, 2001).

The advent of the microprocessor combined with its application in telecommunications has altered the economic meanings of national borders and distance. In particular, the arrival of Intel's 80486 microprocessor together with Microsoft's Windows 3 operating system in the late 1980s meant a breakthrough in the already fast moving ICT revolution. The resulting new communications technologies triggered a virtual spatial revolution in terms of the geography of production in which it was assumed that special distance would loose its meaning. According to The Economist, "The death of distance as a determinant of the cost of communications will probably be the single most important economic force shaping society in the first half of the next century." What the telecommunications revolution has done is to reduce the cost of transmitting information across geographic space to virtually zero. At the same time, the microprocessor revolution has made it feasible for nearly everyone to participate in global communications.

Globalization would not have occurred to the degree that it has if the fundamental changes were restricted to the advent of the technological changes. It took a political revolution in significant parts of the world to reap the full benefits from these technological changes. The political counterpart of the technological revolution was the increase in democracy and concomitant stability in areas of the world that had previously been inaccessible. The Cold War combined with internal political instability rendered potential investments in Eastern Europe and much of the developing world as risky and impractical. During the post-war era most trade and economic investment was generally confined to Europe and North America, and later a few of the Asian countries, such as Japan and the Asian Tigers. Trade with countries behind the iron

\footnotetext{
${ }^{6}$ Globalization describes the process by which regional economies, societies, and cultures have become integrated through a global network of communication, transportation, and trade. The term is sometimes used to refer specifically to economic globalization: the integration of national economies into the international economy through trade, foreign direct investment, capital flows, migration, and the spread of technology (Wikipedia, November 2010).

7 “The Death of Distance,” The Economist, 30 September 1995.
} 
curtain was restricted and in some cases prohibited. Even trade with Japan and other Asian countries was highly regulated and restricted. Similarly, investments in politically unstable countries in South America and the Mid-East resulted in episodes of national takeovers and confiscation where the foreign investors lost their investments (Penrose, Joffe, Stevens, 1992). Such political instability rendered foreign direct investment outside of Europe and North America to be particularly risky and of limited value. In other words, the energy and focus devoted to maintain geopolitical balance was freed up to boost geo-economic growth.

The fall of the Berlin Wall in 1989 and the subsequent downfall of communism in Eastern Europe and the former Soviet Union was a catalyst for stability and accessibility to parts of the world that had previously been inaccessible for decades. The Soviet empire quickly vanished together with its friendship prices and raw material subsidies. ${ }^{8}$ Within just a few years it became possible not just to trade with, but also to invest in countries such as Hungary, the Czech Republic, Poland, and Slovenia, as well as China, Vietnam, and Indonesia. For example, India became accessible as a trading and investment partner after opening its economy in the early 1990s. As Thurow (2002, pp. 25-26) pointed out, "As long as communism was believed to be a viable economic system, there were limits to global capitalism whatever the technological imperatives. Capitalism could not go completely global because much of the globe was beyond its reach. Forty percent of humanity lived under communism.”

The gaping wage differentials existing while the Wall stood and much of the communist world was cut off from the West were suddenly exposed in the early 1990s. There were not only unprecedented labor cost differentials but also massive and willing populations craving to join the high levels of consumption that had become the norm in Western Europe and North America (Jensen, 1993). Of course, the productivity of labor is vastly greater in the West, which compensates to a significant degree for such large wage differentials. Still, given the magnitude of these numbers both trade and investment have responded to the opportunities and restrictions which surfaced after the demise of the communist world.

While the most salient feature of globalization involves interaction and interfaces among individuals across national boundaries, the more traditional measures of transnational activity reflect an upward trend of global activities. ${ }^{9}$ These traditional measures include trade (exports and imports), foreign direct investment (inward and outward), international capital flows, and inter-country labor mobility. The overall trend for all of these measures has been strongly positive. The world trade of goods and services increased five-fold between 1985 and 2007 and more than doubled since 1996 (OECD, 2008 and 2009) while trade in goods experiences even higher growth rates.

A specific manifestation of globalization involves (inward) foreign direct investment, which has increased for all world countries from an average of 0.5 trillion dollars in the last decade of the last century to 1.5 trillion in 2006 in real terms. The increase in global FDI has also not been solely the result of a greater participation by countries previously excluded from the world economy. In the European Union (inward) FDI as a percentage of gross fixed capital formation increased from an average of $12 \%$ for the last decade of the last century to $18 \%$ in 2006. For the US these percentages stayed the same (7\%), whereas for the UK it nearly doubled from $18 \%$ to $34 \%$. The stock of FDI for all world countries as a percentage of gross domestic

\footnotetext{
8 “After the Soviet Collapse: a Globe Redrawn,” The Economist, 5 November 2009.

${ }^{9}$ There are many statistics about the increase of international trade and transactions. Inferences about the degree of and increase in globalization based on international trade statistics miss an important point - it is the quality and not just the quantity of international transactions that have changed. Interaction among individuals adds a very different quality to the more traditional measures of trade, foreign direct investment, and capital flows and also has very different implications for the development of economic activities. This additional quality contributed by the transnational interactions of individuals, and not just arm's-length transactions by corporations, exposes people to ideas and experiences that were previously inaccessible (Cairncross, 1997; Castells, 2001).
} 
product increased from an average of $8 \%$ in the last decade of the last century to $25 \%$ in 2006 (UNCTAD, 2007). Offshoring, i.e., outsourcing across international borders, accounts for a large share of the increase in global FDI. Both captive offshoring (moving activities abroad but keeping them in the company) and outsource offshoring (moving activities abroad to firm outside the company) contribute to this increase (UNCTAD, 2004; 2009; EIM, 2009). A combination of location, internationalization and ownership advantages (Agarwal and Ramaswami, 1992) may explain whether and how outsourcing takes shape. Cost reductions, availability and quality of input factors and growth potential are among the most important drivers of offshoring (Nachum and Zaheer, 2005).

The outward foreign direct investment from the developed countries is a manifestation of outsourcing and offshoring (Friedman, 2005), which corresponds to displaced employment in the home country. The displaced employment of workers with capabilities and competencies provides an opportunity for (nascent) entrepreneurs to redeploy those workers by creating value in a newly formed organization. Numerous studies have documented the reduction of employment in mature and traditional industries, which are outsourcing and offshoring production to lower cost countries (Audretsch, 2007b; EIM, 2009). Similarly, a rich literature has documented the extent to which entrepreneurial startups are spawned from opportunities provided by displaced workers (Thurik, Carree, Van Stel and Audretsch, 2008). Thus, as globalization spreads, employment tends to stop increasing, and even decreases in the large, incumbent firms, generating entrepreneurial opportunities for new startups and SMEs.

\section{ICT and the demise of the Soviet system}

A third factor conducive to small entrepreneurial firms comes directly from Fukuyama's (1992) observation that "the end of history" had occurred, with the demise of communism. Not only did this have enormous consequences in the political realm but it also corresponded to promoting the shift from the managed to the entrepreneurial economy. However, it should be emphasized that the demise of communism, or "the end of history" was not independent of the two factors already discussed - ICT and globalization. In fact, this section will show that the demise of Soviet communism is, in large part, attributable to the advent of ICT. Below we will discuss arrow numbered 4 of Figure 1.

After a rapid transition from a rural, agricultural society the Soviet Union was an urban and industrialized country by the early eighties of the last century. Moreover, it had become a superpower that, together with the US, dominated the global political agenda. However, what had been considered a powerful economy in the beginning of the eighties suddenly disappeared in the beginning of the nineties. The early theories about the demise of the Soviet Union (i.e. the generic non-viability of the socialist economic system, the rise of a popular revolution against the system, the existence of foreign pressures, and the betrayal at the very top of the Communist Party) are contested by Kotz and Weir (1997) who show that, even though these theories played an important role in the collapse of the system, the main dismantling factor has been the combination of a series of hasty economic reforms and the fact that a powerful group coming from the party-state elite became capitalists along the way. How could this happen after seventy years of allegedly successful regime? It seems that the role of ICT and its inevitable relationship with democracy and economic growth are behind the demise of the Soviet system (Brown, 2009; Kedzie, 1997; Robinson, 1995; Shane, 1994; Shultz, 1985).

The surprisingly resilient and long-lasting Soviet system was to a large extent based upon rigid control of information and sophisticated central planning methods (Brown, 2009). Its fall was remarkably accidental. It was also unexpected for it was hardly documented that communism was a less efficient economic engine than its capitalist counterpart. The control of 
information together with uncontested and jubilant planning results shielded the cracks in the system until Mikhail Gorbachev came to power in 1985. Believing that communism and democracy were complementary he set in motion structural reform policies. ${ }^{10}$ Below we will defend that these policies came too late for two reasons: not just the use of ICT was at odds with the control of information and the central planning methods but also their development could not keep pace with what the capitalist system could deliver.

By the late seventies the Soviet Union was already lagging behind in ICT when compared to the Western world. For instance, while the US had over 250,000 computers in operation in 1978, the Soviet Union had roughly 18,000 to 28,000. This difference was even higher by 1988 , when there were only 100,000 to 150,000 personal computers in the Soviet Union compared to over 40 million in the United States (Robinson, 1995). The technical intelligentsia which under Stalin labored in prison laboratories and later in secret scientific institutes and even towns could not keep up which its counterparts. As a consequence, the gap in efficiency, quality and development between the Soviet economy and the Western economies was becoming wider. Moreover, the Soviet economy had begun to stagnate (Brown, 2009; Kotz and Weir, 1997; Shane, 1994). After a period of minor attempts to improve the economic performance, a new leader, Mikhail Gorbachev, experienced the pressures for change from below and undertook a series of structural reform policies that aimed to renew the Soviet socialism (Gorbachev, 1987; Kotz and Weir, 1997). In a speech given before the General Assembly of the United Nations in 1988, he showed to be aware that democracy and the adoption of new technologies were the way to obtain economic growth in the new information era which was being controlled by Western economies (Kedzie, 1997). Actually, Gorbachev sought to take advantage of the market economy tools without destroying socialism, by capitalizing on ICT while maintaining control over information (Shane, 1994). However, this strategy was incompatible since participation in the technological and information revolution inevitably increases information flows without the control of the state, leading to the "Dictator's dilemma" (Shultz, 1985) according to which authoritarian regimes have to choose between ensuring economic growth and keeping social control. Despite efforts to deal with this dilemma, the Soviet system eventually fell with the collapse of the Soviet Union two years after the fall of the Berlin Wall. Engineering society may have worked under Peter the Great (importing technologies), Alexander the Second (abolishing serfdom) and Stalin (wiping out the agricultural population) but Gorbachev's task to tell ICT engineers what to invent proved fruitless.

During the late eighties and early nineties, the Soviet system was not longer isolated from the rest of the world. International flow of e-mails provided Soviet intellectuals and media with information from the West (Kedzie, 1997). Through the access to new mass media based on advanced ICT, Soviet citizens were able to see the advantages and opportunities of capitalism. More and more information about the Western lifestyle became available in the Soviet Union through ICT (Ganley, 1996). In particular, most members of the party-state elite became aware of the gap between the way they lived in the socialist system and the way their counterparts lived in the capitalist system (Kotz and Weir, 1997). Brown (2009) calls them "within-system reformers". In earlier times, this would not have happened since no means of rapid communication and information transfer were available, but the introduction of new ICT in the eighties made it possible to be informed about how alternative societies and economies worked and thrived. Likewise, deeply rooted socialist beliefs were undermined by most new media that not only criticized the Soviet system but also promoted views opposing socialism (Kotz and Weir, 1997). Furthermore, the access to information allowed Soviet people to discover that much of what they had been taught about the Soviet history was false (Shane, 1994).

\footnotetext{
${ }^{10}$ These perestroika policies aimed at democratization of institutions and introduction of market economy elements. It had three main dimensions: glasnost or openness (less censorship and greater freedom of information and thought); radical economic reform; and democratization of political institutions.
} 
Since ICT not only allows people to be well informed, but also to discovers business opportunities, it is an essential phenomenon with social and economic implications fostering entrepreneurship. While this mechanism became more and more relevant in the West, it also started to frustrate the constraints of private business activities under the Soviet system from the mid-eighties onwards. Although the Soviet Union was partially fuelled by ICT, these new and costly technologies were mostly accessible to members of the party-state elite (Kedzie, 1997). Not surprisingly, most new firms were started by them. Obviously, scientists, engineers and inventors who were frustrated by the constraints of the Soviet system also became entrepreneurs in the process, and in the early nineties the new group of Soviet capitalists emerged mainly from the party-state elite (Kotz and Weir, 1997). Most business opportunities in that time were available only in domestic and international trading and financial speculation (Kotz and Weir, 1997). Such activities require effective connections and, as Kotz and Weir (1997) argue, the party-state elite were expected to be the most likely group to have such connections. Likewise, ICT had a sizeable impact on both activities since they provided the ability to reach connections and networks not only inside the borders of the Soviet Union, but also abroad. In fact, technological advancements and low-cost communication technologies allow entrepreneurs to discover and take advantage of international opportunities (Oviatt and McDougall, 1994).

The access to information is inevitably related to democracy: ICT is a great support to democracies since they allow higher information flows and tend to foster greater societal openness, freedom and dialogue (Kedzie, 1997; Hiebert, 2005). Although the centralized government made a great effort to accommodate the country to new ICT, the still-rigid Soviet system was unable to apply these technologies for economic development and competitiveness (Robinson, 1995). ICT offered new economic opportunities only to those economic agents who sought to capitalize on private business, and simultaneously provided political opportunities to the alternative opposition forces that sought to get power against the authoritarian control. That is the reason why ICT played an important role in the demise of the Soviet system, especially in facilitating and accelerating the collapse (Ganley, 1996).

Thus, ICT made the command and control vertically hierarchical decision making organizational structure inherent under Soviet communism incompatible with the faster, horizontal, and more flexible decision making rendered feasible by the new technologies. The competitive advantage of large, vertically integrated decision making hierarchies is processing information that links demand to production from the decision makers at the top of the hierarchy down to the production floor. By contrast, ICT made it possible to link demand conditions to the production floor while bypassing much of the decision making hierarchy, thus rendering flatter and less hierarchical organizations more competitive. However, placing the decision making for production into the hand of workers at the production level was and remains incompatible with communist style planning. Thus, according to Thurow (2002, pp. 25-26), "Much of the world is throwing away its communist or socialist inheritance and moving towards capitalism. Communism has been abandoned as unworkable (China), imploded (USSR), or has been overthrown (Eastern Europe)."

\section{Responses in the managed economies}

The shift away from the success and viability of the managed economy, beginning in the 1970s, was not without consequences and a response from both the public and private sectors (arrows numbered 5 of Figure 1). However, the timing of both the consequences and the public and private responses was not identical on both sides of the Atlantic. Rather, the process of responding to the demise of the managed economy, and purposefully pursing the entrepreneurial economy diffused across geographic space and across national boundaries. 
It is generally believed that the United States suffered the consequences of and therefore began to respond to the consequences of globalized production earlier than did Europe. This may have reflected a disparity in growth rates as contemporary globalization was taking form. In the 1990s, the growth rates between the U.S. and Europe appeared to be diverging rather than converging. Indeed, the European countries have been relatively slow to move from the managed economy to the entrepreneurial economy (Audretsch and Thurik, 2001 and 2004). Clearly, the European policy response varied across countries (Audretsch, Thurik, Verheul and Wennekers, 2002; Audretsch, Grilo and Thurik, 2007; Thurik, 2009). Nevertheless, a process of convergence towards the entrepreneurial economy between Europe and the U.S. has been taking place. Five distinct stages can be discerned of the evolution of the European stance towards the entrepreneurial economy (Audretsch, Thurik, Verheul and Wennekers, 2002, p. 4-6).

The first stage was denial and occurred during the late 1980s. During the denial stage, European policy makers looked to the most brilliant manifestation of the entrepreneurial economy, Silicon Valley, with disbelief. Europe was used to facing a competitive threat from the large well-known multinational American corporations; not from nameless and unrecognizable start-up firms in exotic industries such as software and biotechnology. Twenty years ago firms such as Apple Computer and Intel were interesting newcomers but were irrelevant competitors in the automobile, textile, machinery and chemical industries; then the obvious engines of European competitiveness.

The denial was that economic growth, competitiveness and employment creation were best obtained through entrepreneurship. The policy focus in Europe had been on large-scale corporations as the engine of economic growth. One of the visionaries of a united Europe, Servan-Schreiber (1968, p. 153), warned of the "American Challenge" in the form of the "dynamism, organization, innovation, and boldness that characterize the giant American corporations." Because large corporations were considered to be the engine of growth, employment creation and competitiveness, Servan-Schreiber (1968, p. 159) advocated the "creation of large industrial units which are able both in size and management to compete with the American giants” (1968, p. 159). According to Servan-Schreiber (1968, p. 159), "The first problem of an industrial policy for Europe consists in choosing 50 to 100 firms which, once they are large enough, would be the most likely to become world leaders of modern technology in their fields. At this moment we are simply letting industry be gradually destroyed by the superior power of American corporations.” In 1980 Servan-Schreiber went a step further announcing the end of the dominance of manufacturing, the revolutionary role of the microprocessor and the difficulties the Third World will have coping these regime switches (ServanSchreiber 1980).

The blueprint for European integration that ultimately was realized under the Maastricht Treaty, was drafted in the 1988 Cecchini Report. The economic rationale for European integration was explicitly stated and measured in terms of efficiencies gained from realizing scale economies afforded by an expanded internal market. The gain from an integrated European economy was analyzed and measured in terms of increased firm size. The impact and contribution of entrepreneurship remained the invisible man of European integration.

The second stage, during the mid-1990s, was recognition. Europe recognized that the entrepreneurial economy in Silicon Valley delivered a sustainable long-run performance. But it held to its traditional products while embracing the theory of comparative advantage and channeling resources into traditional moderate technology industries.

Econometric studies of comparative advantage typically identified the United States as having the comparative advantage in the most technologically advanced industries, such as computers and software (Bowen, Leamer and Sveikauskas, 1987). Europe had the comparative advantage in moderate technology industries, such as machine tools and automobiles (Bowen, 
Leamer and Sveikauskas, 1987). Similarly, studies identifying national systems of innovation identified the United States as having institutions and policies conducive to radical and breakthrough innovations (Nelson, 1993). By contrast, the institutions and policies of Europe were more conducive to incremental innovation in existing industries (Nelson, 1993).

Thus, during this second stage Europe's most important economy, Germany, would provide the automobiles, textiles and machine tools. The entrepreneurial economy of Silicon Valley, Route 128 and the Research Triangle would produce the software and microprocessors. Each continent would specialize in its comparative advantage and then trade with each other.

The third stage, during the second half of the 1990s, was envy. There were two different aspects of this third stage. The first aspect revolved around disparities in the economic performance, and in particular growth and unemployment, between Europe and the United States. The second aspect involved the perceived ability for Europe to modify its institutions and policies away from the traditional focus on physical capital, which underlie moderate technology industries such as automobiles, machine tools, and metalworking, and instead shift the policy and institutional priority towards knowledge-based entrepreneurship. By the mid1990s, Europe exhibited a foundering economic performance, but at the same time it was widely thought that its traditions, cultures and institutions precluded a shift to the entrepreneurial economy. ${ }^{11}$

As the entrepreneurial economy continued to diffuse across the United States, most policy-makers despaired that European traditions, institutions, culture, and values were seemingly inconsistent and incompatible with the entrepreneurial economy. ${ }^{12}$ They should have concluded that the concept of comparative advantage had yielded to the different, but better, concept of dynamic competitive advantage.

As European unemployment in countries such as Germany, France, and Spain soared into double digits and growth stagnated by the mid-1990s, the capacity of the entrepreneurial economy in places like Silicon Valley to generate both jobs and higher wages became the object of envy. The United States and Europe seemed to be on divergent trajectories. The separate but equal doctrine from the concept of comparative advantage yielded to the different but better doctrine of dynamic comparative advantage. This was reflected by the strikingly divergent rates of economic growth and corresponding unemployment rates between the two sides of the Atlantic during the 1990s. At the start of the decade, in 1991, per capita GDP barely differed between the Untied States and the leading European counterparts. For example, GDP per capita was only $\$ 1,000$ higher in the United States than in France. The gap was somewhat higher, \$2,000 with Italy and Germany, and \$5,000 with the United Kingdom (Thurow, 2002)

However, by 2001, the trans-Atlantic gap in GDP had increased to $\$ 11,000$ with the United Kingdom, \$12,000 with Germany, \$13,000 with France, and \$16,000 with Italy. Taken as a whole, the trans-Atlantic gap in the standard of living, as measured by GDP per capita, was greater at the turn of the century than it had been in nearly four decades during the-world war II era (Thurow, 2002). The trans-Atlantic gap in economic growth was reflected in divergent unemployment rates. Even as unemployment decreased to the lowest levels since the 1960s in the United States, on the other side of the Atlantic, unemployment grew to postwar highs. This

\footnotetext{
${ }^{11}$ For example, in Germany in 1998 the unemployment reached nearly 13 percent, representing 4.8 million people, which was the highest level since the pre-Nazi Weimar Republic (International Harald Tribune, 2001, November 22, 1).

${ }^{12}$ For example, Joschka Fischer, a Green party member and the then foreign minister of Germany, mourned in 1995 that, "a company like Microsoft would never have a chance in Germany" (The Economist, Those German banks and their industrial treasures, January 21, 1995, 75-76). Similarly, (Strukturwandel in Deutschland, 1994, February 6, nr 5, 82-83) commented likewise: "Global structural change has had an impact on the German economy that only a short time ago would have been unimaginable. Many of the products, such as automobiles, machinery, chemicals and steel are no longer competitive in global markets. And in the industries of the future, like biotechnology and electronics, the German companies are barely participating." See also Audretsch, Keilbach and Lehman (2006) and Casper (2007).
} 
divergence in economic performance in the 1990s was reflected by the creation of 22 million net new jobs in the United States, while no new net jobs were created in Europe.

In fact, it was not just the newly created entrepreneurial companies, such as Microsoft, Intel, and Apple Computers that seemed to outperform Germany as well as the rest of Europe. Thurow (2002) points out that 20 percent of the largest firms that did not grow large as a result of mergers in the world in 2002 were new companies founded in the United States subsequent to 1960. By contrast, there is only one European startup included in the list of the largest enterprises in the world - SAP, which ranked as number 73. As Thurow (2002, p. 35) concluded, "Europe is falling behind because it doesn't build the new big firms of the future.”

The fourth stage, during the last years of the twentieth century, was consensus. European policy makers reached a consensus that - in the terminology of Audretsch and Thurik (2001 and 2004) - the new entrepreneurial economy was superior to the old managed economy and that a commitment had to be forged to creating a new entrepreneurial economy. A broad set of policies were instituted to create a new entrepreneurial economy. European policy makers looked across the Atlantic and realized that if places such as North Carolina, Austin, and Salt Lake City could implement targeted policies to create the entrepreneurial economy, European cities and regions could as well. After all, Europe had a number of advantages and traditions, such as a highly educated and skilled labor force, world-class research institutions and its variety in cultures and hence innovative approaches to new products and organizations. These phenomena would provide a perfect framework for absorbing the high levels of uncertainty inherent to the entrepreneurial economy (Audretsch and Thurik, 2001).

The mandate set forth by the European Council of Lisbon in 2000 certainly reflected the consensus stage. Plagued by stagnant economic growth, unemployment rates which were ratcheting upward, the Lisbon Proclamation committed the European Union to becoming now just the world's leading knowledge economy but also the leading entrepreneurial economy. The new European consensus that only a knowledge-based entrepreneurial economy would generate sufficient and sustainable growth and job creation in Europe was reflected by the observation by Romano Prodi (in his public speech at the Instituto de Empresa in Madrid in 2002), who at the time served as President of the European Commission, "Our lacunae in the field of entrepreneurship need to be taken seriously because there is mounting evidence that the key to economic growth and productivity improvement lies in the entrepreneurial capacity of an economy."

The fifth stage is attainment. The entrepreneurial economy is finally emerging in Europe. Consider the Green Paper on Entrepreneurship of the European Commission (European Commission, 2003) which aims to stimulate debate amongst policy makers, businesses, representative organizations, journalists and scientific experts on how to shape entrepreneurship policy. ${ }^{13}$ It analyses a range of policy options and asks, within the proposed context for entrepreneurship policy, a number of questions suggesting different options on how to reach progress. Some of the highest R\&D intensive countries are in Europe (Scandinavia). Parts of Europe, such as Denmark and Finland, are among the most entrepreneurial countries in the world, based on the results from the Global Entrepreneurship Monitor (GEM). Europe now is home to some of the world's leading most innovative and entrepreneurial clusters in hightechnology and knowledge-based economic activity, such as Munich, Cambridge, and Stockholm. The mandate to create an entrepreneurial Europe is evident by the subsequent Lisbon agenda (an action and development plan for the European Union between 2000 and 2010) and its successor, the Europe 2020 agenda. They both view entrepreneurship in the form

\footnotetext{
${ }^{13}$ See also Audretsch, van Leeuwen, Menkveld and Thurik (2001) and Van Stel, Storey and Thurik (2007) for examples of policy measures promoting the entrepreneurial economy in Europe.
} 
of startups and SMEs as a requisite cornerstone for sustainable growth, competitiveness and employment.

While policy makers went through their successive stages, producers in the high-cost countries confronted with lower cost competition in foreign locations have four options apart from doing nothing and losing global market share: (1) reduce wages and other production costs sufficiently to compete with the low-cost foreign producers, (2) substitute equipment and technology for labor to increase productivity, (3) reorganizing production while subcontracting out non core activities, (4) shift production out of the high-cost location and into the low-cost location and (5) formulate a strategy away from using traditional inputs like land, labor and capital and toward knowledge.

Many of the European and North American firms that have successfully restructured resorted to alternatives (2), (3) and (4). Substituting capital and technology for labor, reorganizing the production chain towards subcontracting along with shifting (parts of) production to lower-cost locations has resulted in waves of Corporate Downsizing throughout Europe and North America. At the same time, it has generally preserved the viability of many of the large corporations (Audretsch and Thurik, 1999). As record levels of both European and American stock indexes indicate, the companies have not generally suffered. For example, already between 1979 and 1995 more than 43 million jobs were lost in the United States as a result of corporate downsizing. This includes 25 million blue-collar jobs and 18 million whitecollar jobs. Similarly, the 500 largest US manufacturing corporations cut nearly five million jobs between 1980 and 1993, or one-quarter of their work force. Although at its most intense in the late 1980s and early 1990s, this wave of corporate downsizing has continued (Burke and Cooper, 2000) despite obvious downsides (Dougherty and Bowman, 1995). A recent study (EIM, 2009) shows that $17 \%$ of all small and medium-sized companies in the EU-27 is engaged in subcontracting activities while $7 \%$ in international subcontracting. The cries of betrayal and lack of social conscience on the part of the large corporations have died in the $21^{\text {st }}$ century because the virtues of the new entrepreneurial economy become clear. The impact of outsourcing and offshoring has been fraught with heightened emotions, "Exporting jobs to where labor is cheapest may be the most efficient allocation of capital, but it results in unemployment in the U.S. and is a contributing factor to a trade deficit that increases by an average of $\$ 1.5$ billion a day. To the argument that the cheap goods sold back into our markets offset the loss of exported jobs, there is only one humane response: Tell that to the unemployed who are too poor to purchase the goods." 14

Downsizing, outsourcing and even offshoring is not sufficient to safeguard the role of many European and North American firm on the world arena. There is also a wage constraint. Much of the policy debate responding to the twin forces of the telecommunications revolution and increased globalization has revolved around a trade-off between maintaining higher wages but suffering greater unemployment versus higher levels of employment but at the cost of lower wages rates. There is, however, an alternative. It does not require sacrificing wages to create new jobs, nor does it require fewer jobs to maintain wage levels and the social safety net. This alternative involves shifting economic activity out of the traditional industries where the highcost counties of Europe and North America have lost the comparative advantage where even downsizing has its limits and into those industries where the comparative advantage is compatible with both high wages and high levels of employment - knowledge-based economic activity (Audretsch and Thurik, 1999; Audretsch, 2007b).

These developments have led to the emergence of strategic management policy - not for firms, but for regions (Audretsch, Grilo and Thurik, 2011). The strategic management of places is the strategic deployment of policies to create competitive advantage, sustainable growth and

${ }^{14}$ Ilana Mercer, “Downsizing Jobs, Outsourcing Lives,” http://www.wnd.com/news/article.asp?ARTICLE_ID=32789. 
employment by a community, city, state, or country or even broader political unit, such as the European Union (Audretsch, 2007a and 2007b).

As long as corporations were inextricably linked to their regional location by substantial sunk costs, such as capital investment, the competitiveness of a region was identical to the competitiveness of the corporations located in that region. A quarter-century ago, while the proclamation, "What is good for General Motors is good for America" may have been controversial, few would have disagreed that "What is good for General Motors is good for Detroit.” And so it was with US Steel in Pittsburgh and Volkswagen in Wolfsburg. As long as the corporation thrived, so would the region.

As globalization has rendered not only the degree to which the traditional economic factors of capital and labor are sunk but also shifted the comparative advantage in the high-wage countries of North America and Europe toward knowledge-based economic activity, corporations have been forced to shift production to lower-cost locations. This has led to a delinking between the competitiveness of firms and regions. The advent of the strategic management of places has been a response to the realization that the strategic management of corporations includes a policy option not available to a region-changing the competitiveness to generate a better economic performance. ${ }^{15}$

\section{The knowledge filter}

The policy response to globalization, both in public policy debates as well as in the economics and the strategic management literature, was to shift the source of competitiveness and growth away from physical capital and towards knowledge and ideas. In the policy debates this was made clear in the Lisbon Mandate, and in the economics literature it emerged as the critical factor underlying economic growth in the new growth theory or models of endogenous growth (Lucas, 1988 and Romer, 1990). In the strategic management literature a new focus on the importance of knowledge as the crucial resource for sustained competitive performance emerged. For example, Cohen and Levinthal (1989) identified the importance of knowledge investments for firm learning and ultimately innovation to enhance competitive advantage, Teece (1993) identified the key role of dynamic learning in creating a dynamic competitive advantage, while Barney (1991) identified the importance of intangible assets as a crucial source of competitive advantage.

The endogenous growth theory assumes that an economy automatically benefits from its investments in new knowledge (Lucas, 1988; Romer, 1990). The idea is that knowledge behaves like a public good that an entire economy can use. While Solow was attributed with suggesting that knowledge "falls like manna from heaven", in the endogenous growth models, it can be interpreted as blowing over from the neighbor. This use by more than one firm or economic agent is particularly conducive to economic growth.

In the knowledge production function approach (Griliches, 1979), firms exist exogenously and then engage in the pursuit of new knowledge as an input into the process of generating innovative activity. Knowledge as an input in a production function is inherently different than the more traditional inputs of labor, capital, and land. While the economic value of the traditional inputs is relatively certain, knowledge is intrinsically uncertain and its potential value

\footnotetext{
${ }^{15}$ The strategic management of places is an updated version of the older tradition of Standortpolitik in Germany. Traditionally, in France the top-down state-led orientation prevented specific local policies from blossoming. Decentralization initiatives (métropoles d'equilibre such as Toulouse; Silicon Valley approaches such as Sophia Antipolis) were directed from Paris starting in 1960s. Increasing regional autonomy and the desire to build high tech clusters (Grenoble; Montpellier) create room for the strategic management of places à la française (e.g., recent policy incentives to foster international competitivity though pôles de croissance).
} 
is asymmetric across economic agents (Audretsch, Houweling and Thurik 2000). The most important source of new knowledge is considered to be $R \& D$ while other sources include a high degree of human capital, a skilled labor force, and a high presence of scientists and engineers.

Although there is, of course, a great deal of evidence that knowledge (R\&D stock) leads to growth, some countries seem to benefit more from investments in new knowledge than others do. The US, for example, is considered to be much stronger than Europe in the commercialization of new knowledge. This effect is sometimes referred to as the Swedish paradox (Ejermo and Kander, 2006) or the European paradox (Audretsch, 2007a). Investments in new knowledge are only a necessary condition; new knowledge still needs to be exploited and put to commercial use so that it can translate into a higher level of competitiveness and subsequent economic growth. This translation changes over time in terms of what knowledge is created and where (Carlsson, Acs, Audretsch and Braunerhjelm, 2009). The barrier between knowledge and its commercialization is termed the knowledge filter (Audretsch, 2007a; Carlsson, Acs, Audretsch and Braunerhjelm, 2009; Acs, Audretsch, Braunerhjelm and Carlsson, 2010). The knowledge filter is defined as the gap that occurs between knowledge created by investments and other activities, and the knowledge that is actually made use of in generating innovative activity (see arrows numbered 6 in Figure 1).

The production of knowledge can lead to spillovers: individuals or organizations other than the creators of knowledge may benefit from the knowledge that the creator has produced. Thus, by investing in knowledge, a firm not only increases its own level of knowledge but also makes a contribution to the aggregate stock of knowledge (Romer, 1986; Lucas, 1993; Griliches, 1998). For example, if a firm produces new knowledge and is granted a patent, the information included in the patent becomes accessible to the general public and to competitors. A competitor may use the information from the patent for its own research and invest in related knowledge, which might then lead to new patents or innovative products: knowledge may spill over from one firm to another. One of the recurring findings of the extensive research on knowledge spillovers in many different contexts is that geographical proximity matters if knowledge spillovers are to occur. Although it is possible that knowledge spills over to firms or individuals far away from the creator of knowledge, it has been shown that these spillovers are more likely to occur on a local level (Jaffe, Trajtenberg and Henderson, 1993; Bottazzi and Peri, 2003). ${ }^{16}$

Entrepreneurship is characterized by its role in opportunity recognition, discovery, and creation (Shane and Venkataraman, 2000). Little is known, however, about the source of opportunities (Braunerhjelm, 2008). The knowledge spillover theory of entrepreneurship (Audretsch and Lehmann, 2005; Audretsch and Keilbach, 2007, 2008; Acs, Braunerhjelm, Audretsch and Carlsson, 2009) helps to close this gap. Knowledge spillovers are suggested as a possible source of entrepreneurial opportunities. This has also been termed endogenous entrepreneurship $^{17}$. Due to the non-rival nature of knowledge as an asset, it may spill over such that the producers of knowledge are not able to appropriate the entire value of their knowledge for themselves. These spillovers serve as a source of opportunities for other firms and for individuals who want to start their own business. The knowledge spillover theory of entrepreneurship states that entrepreneurial activity is greater in the presence of higher investments in knowledge. This argument is supported by Audretsch and Lehmann (2005), among others, who show that regions with greater investments in new knowledge also have

\footnotetext{
${ }^{16}$ The Internet is a perfect open source terrain for would-be inventors. Websites like www.instructables.com and www.wikiHow.com are meeting places thriving on spillovers while festival type markets like Maker Faire are the offline counterpart.

${ }^{17}$ The theory starts from the assumption that given constant individual characteristics entrepreneurial decisions are driven by the context, in particular by the knowledge intensity of the context. Hence, entrepreneurship is not just exogenously driven by individual characteristics, behaviors and traits but also by the endogenous response to opportunities created by the context (Audretsch, 2007a; Acs, Braunerhjelm, Auderstch and Carlsson, 2009; Acs, Audretsch, Braunerhjelm and Carlsson, 2010).
} 
higher start-up rates. Another facet of the theory refers to entrepreneurial performance. Based on the assumption that knowledge spillovers increase economic performance (Lucas, 1988; Romer, 1990; Glaeser, Kalla, Schenkman and Shleifer, 1992) and that this relationship is moderated by geographical proximity (Jaffe, Trajtenberg and Henderson, 1993; Bottazzi and Peri, 2003), it is suggested that opportunities for entrepreneurship are superior when the ability to access knowledge spillovers from geographically proximate sources is greater. This can be the case if the entrepreneur is located in close proximity to universities, large high-tech firms or other research-intensive institutions that produce knowledge (Audretsch and Lehmann, 2005).

Thus, while the Solow and Romer models viewed knowledge as automatically spilling over for commercialization leading to innovation and economic growth, the view posited by the knowledge spillover theory of entrepreneurship suggests that, as a result of the knowledge filter, knowledge will not spill over for commercialization unless an entrepreneur provides a conduit for knowledge spillovers by creating a new firm. While the Solow model views knowledge as exogenous and falls "like manna from heaven", and the endogenous growth model of Romer views knowledge as endogenous, in that purposeful investments create positive externalities, the knowledge spillover theory of entrepreneurship suggests that knowledge created in the context of an incumbent organization will only spill over, at least in some cases, when an entrepreneur purposefully creates a new firm to commercialize and innovate on the basis of that knowledge created in one organizational context but ultimately commercialized in the context of the new, entrepreneurial firm. ${ }^{18}$

\section{Prosperity and entrepreneurship}

The arrows numbered 7 in Figure 1 depict how prosperity intermediates the relationship involving ICT and globalization, which in turns shapes the roles played by startups and SMEs. In the sections above, we describe how the ICT revolution, together with globalization as the governing principle of economic behavior and spurred by the demise of the communist system, led to more room for SMEs and entrepreneurship through new organizational structures (outsourcing and offshoring) and the higher emphasis on knowledge as a production factor. These higher levels of prosperity lead to a more service oriented economy (Bryson, Keeble and Wood, 1997), a differentiation in consumer demands (Piore and Sabel, 1984) and a shift in occupational preferences (Uhlaner and Thurik, 2007). All three, independent of organizational and knowledge based restructuring, lead to more room for entrepreneurship in the form of startups and SMEs. First, the growth in service orientation of developed economies is due to relatively high income elasticities of personal and social services combined with their relatively low labor productivity. Second, the increase in individual wealth has led to growing differentiation of consumer preferences, and hence, business opportunities (Brock and Evans, 1989). The advantages of low price made possible by exploitation of scale and scope of the typical multinational enterprise of the managed economy lost their meaning in the face of consumers' taste for variety. Third, the supply side of entrepreneurship is influenced by the drivers of occupational choice. High levels of prosperity will give prominence to immaterial motivations such as autonomy and self-realization. These motivators are at the heart of the entrepreneurial choice. It is shown that, in spite of long and intense working hours under a high level of uncertainty, the self-employed have a higher job-satisfaction than those working for them (Blanchflower and Oswald, 1998; Blanchflower, 2000; Hamilton, 2000; Millan, Hessels, Thurik and Aguado, 2011).

\footnotetext{
${ }^{18}$ See Braunerhjelm (2008) for a literature survey covering the conditions, the characteristics and the consequences of knowledge creation and knowledge diffusion, including the role of entrepreneurship and economic growth.
} 
Finally, prosperity may go together with low levels of unemployment. We know that the so-called unemployment push, refugee of desperation effect, suggests that the decision to become an entrepreneur is a response to either being unemployed or else the perception of dismal future employment prospects (Thurik, Van Stel, Carree and Audretsch, 2008). This view links back to the work of Knight (1971) that has been extended to the theory of occupational choice. One can also word it differently: economic development tends to be accompanied by rising real wages raising the opportunity costs of self-employment which makes wage employment more attractive (Lucas, 1978). This view may work against the five mechanism mentioned above. However, there is a counterargument: entrepreneurial activities are not just the result of the push effect of (the threat of) unemployment but also of pull effect produced by a thriving economy.

Our arguments are supported by empirical evidence which shows that for high levels of economic development, i.e., in the entrepreneurial economy, there is a clear tendency that economic development goes together with the level of entrepreneurial activity (Carree, van Stel, Thurik and Wennekers, 2007; Bosma, Jones, Autio and Levie, 2007; Wennekers, van Stel, Carree and Thurik, 2010).

The arrows from ICT, globalization and knowledge production/filter leading to prosperity in Figure 1 will not be discussed. It is beyond the scope of the present paper to motivate that technology, i.e., ICT and globalization lead to economic growth. We refer to the numerous studies based upon the R\&D capital approach. See Erken, Donselaar and Thurik (2009) for a survey. That knowledge, once converted into innovations (and hence having passed the knowledge filter), lead to prosperity is already motivated in section six. See also Block, Thurik and Zhou (2009) for a survey.

\section{Conclusion}

The inventions of division of labor, economies of scale and scope, paid labor and the fine tuned cooperation between man and machine following the industrial revolutions conceal what the original economic role of man was in the era of 'hunting and gathering'. Assuming that it was one of a high level of independence, to be compared with self-employment, mostly for lack of employers, capital and organizational sophistication, economic history can indeed be interpreted as a long quest away from self-employment and towards the invention of the large multinational enterprise (Wennekers, Van Stel, Carree and Thurik, 2010). This enterprise was clearly the dominant form of organization until the 1980s. Not surprisingly, Robert Solow (1956) suspected capital and labor as the main sources of growth, which in his later empirical work appeared to be the case only to a limited degree and which led to the introduction of the 'Solow residual'. Capital and labor, however, were factors best utilized in large scale production. Also, the increasing level of transaction costs (Coase, 1937) incurred in large-scale production demanded increasing firm size. Statistical evidence, gathered from both Europe and North America, points towards an increasing presence and role of large enterprises in the economy in this period (Caves, 1982; Brock and Evans, 1989; Teece, 1993). This was the era of mass production when economics of scale and scope seemed to be the decisive factor in dictating efficiency. This was the world described by John Kenneth Galbraith (1956) in his theory of countervailing power, where the power of 'big business' was balanced by that of 'big labor' and 'big government'. Stability, continuity and homogeneity were the cornerstones of the managed economy (Audretsch and Thurik, 2001). Rising levels of prosperity absorbed the products and services created by typical multinational enterprise in this managed economy.

A recent literature suggests that the managed economy has been replaced by the

entrepreneurial economy throughout all developed countries (for instance, Audretsch and 
Thurik, 2000 and 2001; Baumol, 2002; Florida, 2002; Wennekers, van Stel, Thurik and Reynolds, 2005; Baumol, Litan and Schramm, 2007; Audretsch, 2007b; The Economist, 2010). What has been less clear is why such an important switch took place. The findings of this paper point to the key role of ICT in triggering the shift away from the managed economy along with the intermediary effect of a host of other factors, such as globalization, the end of communism, and the strategic response of multinational corporations. Recognizing the ubiquitous nature of this switch leads us to rethink the appropriate policy response. This regime switch helped triggering an awakening in policy debates to promote entrepreneurship through “entrepreneurship policy”. Governments, spanning local, city, regional, national and even supranational, such as the EU, began a vigorous and targeted effort to spur the startup of new firms and the growth and survival subsequent to start up.

An important implication of this paper is that focusing on entrepreneurship policy ignores the pervasiveness and prevalence involving the forces triggering the shift from the managed to the entrepreneurial economy. Given the pervasiveness of this shift, promoting startups or their post-entry performance is too narrow of an interpretation of the appropriate policy response. Rather than develop an entrepreneurship policy, the appropriate policy response is to develop policy for the entrepreneurial economy. Figure 1 which attempts to capture the essence of the many links between the advent of the ICT revolution and the emergence of entrepreneurship as central element in the modern economy including the many intermediary effects, also implies that the policy implications are beyond those of creating entrepreneurship policy focusing exclusively on the promotion of new-firm startups and SMEs.

The difference between entrepreneurship policy and policy for the entrepreneurial economy is that the former leaves most institutions and policies unchanged. The focus is on creating instruments that will directly promote the startup of new firms and the performance, typically in terms of growth and survival, of those entrepreneurial startups. This leaves most of the incumbent institutions and policies that do not directly address startups and their performance unchanged. See also Bridge (2010).

By contrast, policy for an entrepreneurial economy leaves virtually no aspect of institutions or policy unchanged. These aspects can be influenced through many channels (Audretsch, Thurik, Verheul and Wennekers 2002; Audretsch, Grilo and Thurik 2007; Thurik 2009). Institutions and policies, spanning education, immigration, the social safety net, health, labor and finance among many others were all designed for the managed economy. The conclusion of this paper is, given the prevalence and pervasiveness of the forces underlying the shift from the managed to the entrepreneurial economy, that their role and contribution needs to be rethought and readdressed for the entrepreneurial economy. Many of the institutions and policies created during the era of the managed economy may actually contribute to the knowledge filter and pose as barriers to entrepreneurship in the entrepreneurial economy.

One poignant example is the enforcement of non-compete agreements, which prohibit employees from using knowledge gained in one firm from leaving that firm and using it in a competing firm. While such agreements may have constituted sensible public policy in the managed economy by enhancing the ability of incumbent firms to appropriate costly investments, Marx, Singh and Fleming (2010) provide compelling empirical evidence showing that enforcement of non-compete agreements lead to a "brain drain" in the form of driving away innovative entrepreneurs. Similarly, linking immigration to employment with a sole firm has been shown by Gaonkar, Agarwal and Ganco (2010) to limit immigrant mobility and therefore reduce the pool of high potential entrepreneurs, which would have an adverse impact in an economy that highly values entrepreneurship. Both of these examples highlight policies that may have made sense in the managed economy but are absolutely counter-productive in the entrepreneurial economy. As these examples suggest, only a fundamental rethinking of 
institutions and public policy will provide an adequate re-alignment as the entrepreneurial economy of this century replaces the managed economy of the previous century.

\section{References}

Acs, Z.J. and D.B. Audretsch (1990), Innovation and Small Firms. MIT Press: Cambridge, MA.

Acs, Z.J., D.B. Audretsch, P. Braunerhjelm and B. Carlsson (2010), 'The Missing Link. Knowledge Diffusion and Entrepreneurship in Endogenous Growth,' Small Business Economics, 34(2), 105-125.

Acs, Z.J., D.B. Audretsch and B. Carlsson (1991), 'Flexible technology and Firm Size,' Small Business Economics, 3(4), 307-319.

Acs, Z.J., P. Braunerhjelm, D.B. Audretsch and B. Carlsson (2009), 'The Knowledge Spillover Theory of Entrepreneurship,' Small Business Economics, 32(1), 15-30.

Agarwal, S. and S.N. Ramaswami (1992), 'Choice of Foreign Market Entry Mode: Impact of Ownership, Location and Internalization Factors,' Journal of International Business Studies, 23(1), 1-27.

Ansari, S.M. and P. Krop (2008), Incumbent Performance in the Face of a Radical Innovation: Paper presented at the Academy of Management, 2008, Anaheim, USA and EURAM 2008, Slovenia.

Archibugi, D. and B.A. Lundvall (2001), The Globalizing Learning Economy. Oxford University Press: Oxford.

Audretsch, D. (1995), Innovation and Industry Evolution. MIT Press: Cambridge, MA.

Audretsch, D.B. (2007a), 'Entrepreneurship capital and economic growth,' Oxford Review of Economic Policy, 23(1), 63-78.

Audretsch, D.B. (2007b), The Entrepreneurial Society. Oxford University Press: Oxford.

Audretsch, D.B., I. Grilo and A.R. Thurik (eds.) (2007), The Handbook of Research on Entrepreneurship Policy. Edward Elgar Publishing Limited: Cheltenham, UK and Northampton, MA.

Audretsch, D.B., I. Grilo and A.R. Thurik (2011), 'Globalization, Entrepreneurship and the Region,' in M. Fritsch (ed.), Handbook of Research on Entrepreneurship and Regional Development. Edward Elgar Publishing Limited: Cheltenham, UK and Northampton, MA, forthcoming.

Audretsch, D.B., P. Houweling and A.R. Thurik (2000), 'Firm Survival in the Netherlands,' Review of Industrial Organization, 16(1), 1-11.

Audretsch, D.B. and M.C. Keilbach (2007), 'The Theory of Knowledge Spillover Entrepreneurship,' Journal of Management Studies, 44(7), 1242-1254.

Audretsch, D.B. and M.C. Keilbach (2008), 'Resolving the Knowledge Paradox: Knowledge-spillover Entrepreneurship and Economic Growth,' Research Policy, 37(10), 1697-1705.

Audretsch, D.B., M.C. Keilbach and E.E. Lehman (2006), Entrepreneurship and Economic Growth. Oxford University Press, Oxford.

Audretsch, D.B., G. van Leeuwen, B.J. Menkveld and A.R. Thurik (2001), 'Market Dynamics in the Netherlands: Competition Policy and the Response of Small Firms,' International Journal of Industrial Organisation, 19(5), 795-821.

Audretsch, D.B. and E.E. Lehmann (2005), 'Does the Knowledge Spillover Theory Hold for Regions?' Research Policy, 34(8), 1191-1202.

Audretsch, D.B. and M. Sanders (2007), Globalization and the Rise of the Entrepreneurial Economy. CEPR Discussion Paper No. DP6247, available at SSRN: http://ssrn.com/abstract=1135485 (June 2010).

Audretsch, D.B. and A.R. Thurik (1999), Innovation, Industry Evolution and Employment. Cambridge University Press: Cambridge.

Audretsch, D.B. and A.R. Thurik (2000), 'Capitalism and Democracy in the 21st Century: from the Managed to the Entrepreneurial Economy,' Journal of Evolutionary Economics, 10(1-2), 17-34

Audretsch, D.B. and A.R. Thurik (2001), 'What is New about the New Economy: Sources of Growth in the Managed and Entrepreneurial Economies,' Industrial and Corporate Change, 10(1), 267-315.

Audretsch, D.B. and A.R. Thurik (2004), 'A Model of the Entrepreneurial Economy,' International Journal of Entrepreneurship Education, 2(2), 143-166.

Audretsch, D.B., A.R. Thurik, I. Verheul and A.R.M. Wennekers (eds.) (2002), Entrepreneurship: Determinants and Policies in the New Economy. Kluwer Academic Publishers: Boston/Dordrecht.

Barney, J.B. (1991), 'Firm Resources and Sustained Competitive Advantage,' Journal of Management, 17(1), 99-120. 
Barney, J.B., (2001), 'Is the Resource-Based Theory a Useful Perspective for Strategic Management Research? Yes,' Academy of Management Review, 26(1), 41-56.

Baumol, W.J. (2002), The Free-Market Innovation Machine. Analyzing the Growth Miracle of Capitalism. Princeton University Press: Princeton, N.J.

Baumol, W.J., R.E. Litan and C.J. Schramm (2007), Good Capitalism, Bad Capitalism and the Economics of Growth and Prosperity. Yale University Press: New Haven/London.

Blanchflower, D.G. (2000), 'Self-employment in OECD Countries,' Labour Economics, 7(5), 471-505.

Blanchflower, D.G. and A.J. Oswald (1998), 'What Makes an Entrepreneur?' Journal of Labor Economics, 16(1), 26-60.

Blau, D.M. (1987), 'A Time-Series Analysis of Self-employment in the United State,' Journal of Political Economy, 95(3), 445-467.

Block, J.H., A.R. Thurik and H. Zhou (2009), What Turns Knowledge into Innovative Products? The Role of Entrepreneurship and Knowledge Spillovers. Erasmus Institute of Management Report ERS2009-049-ORG, Erasmus University Rotterdam.

Bosma, N., K. Jones, E. Autio and J. Levie (2008), Global Entrepreneurship Monitor, 2007 Executive Report. Babson College: Babson Park, MA. / London Business School: London, UK.

Bottazzi, L. and G. Peri (2003), 'Innovation and Spillovers in Regions: Evidence from European Patent Data,' European Economic Review, 47(4), 687-710.

Bowen, H.P, E. Leamer, and L. Sveikauskas (1987), 'Multicountry, Multifactor Tests of the Factor Abundance Theory,' American Economic Review, 77(5), 791-809.

Braunerhjelm, P. (2008), 'Entrepreneurship, Knowledge, and Economic Growth,' Foundations and Trends in Entrepreneurship, 4(5), 451-533.

Breschi, S. and F. Malerba (2005), Clusters, Networks, and Innovation. Oxford University Press: Oxford.

Bridge, S. (2010), Rethinking Enterprise Policy: Can Failure Trigger New Understanding? Houndmills, Basingstoke, Hampshire, England: Palgrave Macmillan.

Brock, W.A. and D.S. Evans (1989), 'Small Business Economics,' Small Business Economics, 1(1), 720.

Brousseau, E. and N. Curien (eds.) (2006), Internet and Digital Economics. Cambridge: Cambridge University Press.

Brown, A. (2009), The Rise and Fall of Communism. London: The Bodley Head.

Brown, C. and J. Medoff (1989), 'The Employer Size-wage Effect,' Journal of Political Economy, 97(5), 1027-1059.

Brown, C., J. Hamilton and J. Medoff (1990), Employers Large and Small. Cambridge, MA: Harvard University Press.

Bryson, J.R., D. Keeble and P. Wood (1997), 'The Creation and Growth of Small Business Service Firms in Post-Industrial Britain,' Small Business Economics, 9(4), 345-360.

Burke, R.J. and C.L. Cooper (eds.) (2000), The Organisation in Crisis: Downsizing, Restructuring and Privatisation. Blackwell: Oxford.

Cairncross, F. (1997), The Death of Distance. Harvard Business School: Boston, Ma.

Carlsson, B., Z.J. Acs, D.B. Audretsch and P. Braunerhjelm (2009), 'Knowledge Creation, Entrepreneurship, and Economic Growth: a Historical Review,' Industrial and Corporate Change, 18(6), 1193-1229.

Carree, M. A., A. J. van Stel, A. R. Thurik and A.R.M. Wennekers (2007), 'The Relationship between Economic Development and Business Ownership Revisited,' Entrepreneurship and Regional Development, 19(3), 281-291.

Casper, S. (2007), Creating Silicon Valley in Europe: Public Policies towards new Technology Industries. Oxford University Press: Oxford.

Castells, M, (2001), The Internet Galaxy: Reflections on the Internet, Business and Society. Oxford University Press: Oxford, UK.

Caves, R. (1982), Multinational Enterprise and Economic Analysis. Cambridge University Press: Cambridge.

Chandler, A.D. Jr. (1990), Scale and Scope: The Dynamics of Industrial Capitalism. Harvard University Press: Cambridge, MA.

Chesbrough, H., W. Vanhaverbeke and J. West (2006), Open Innovation: Researching a New Paradigm. Oxford University Press: Oxford.

Coase, R.H. (1937), 'The Nature of the Firm,' Economica, 4(4), 386-405. 
Cohen, W. and D. Levinthal (1989), 'Innovation and Learning: The Two Faces of R\&D,' Economic Journal, 99(3), 569-596.

Day, G. S. (1981), 'The Product Life Cycle: Analysis and Application Issues,' Journal of Marketing, 45(4), 60-67.

Dougherty, D.J. and E.H. Bowman (1995), 'The Effects of Organizational Downsizing on Product Innovation,' California Management Review, 37(4), 28-44.

Dreher, A., N. Gaston and P. Martens (2008), Measuring Globalisation: Gauging its Consequences. Springer Verlag: Berlin, Heidelberg.

Drucker, P.F. (1985), Innovation and Entrepreneurship: Practice and Principle. Harper Business: New York.

Dyer, J.H. and H. Singh (1998), 'The Relational View: Cooperative Strategy and Sources of Interorganizational Competitive Advantage,' Academy of Management Review, 23(4), 660-679.

EIM (2009), EU SMEs and Subcontracting. EIM/Panteia: Zoetermeer, NL.

Ejermo, O. and A. Kander (2006), The Swedish Paradox. CIRCLE Electronic Working Paper Series 2006/01, CIRCLE: Lund, Sweden.

Erken, H., P. Donselaar and A.R. Thurik (2009), Total Factor Productivity and the Role of Entrepreneurship. Tinbergen Institute Discussion Paper TI09-034/3, Erasmus University Rotterdam.

European Commission (2003), Green Paper Entrepreneurship in Europe, available at: http://ec.europa.eu/enterprise/entrepreneurship/green_paper/index.htm (June 2010).

Florida, R. (2002), The Rise of the Creative Class. Basic Books: New York.

Foray, D. (2004), The Economics of Knowledge. MIT Press: Cambridge, MA.

Friedman, Th.L. (2005), The World is Flat: a Brief History of the Twenty-first Century. Farrar, Straus and Giroux: New York.

Fukuyama, F. (1989), 'The End of History?' The National Interest, 16(summer), 3-18.

Fukuyama, F. (1992), The End of History and the Last Man. Free Press: New York, NY.

Galbraith, J.K. (1956), American Capitalism: The Concept of Countervailing Power. Houghton Mifflin Co.: Boston.

Ganley, G.D. (1996), Unglued Empire: The Soviet Experience with Communication Technologies. Ablex Pub. Corp: Norwood, NJ.

Gaonkar, S., R. Agarwal and M. Ganco (2010), 'Non-Golden Handcuffs: The Strategic Use of immigration Policy by Firms in Creation of Compensation Packages and Barriers to Employee Mobility,' unpublished paper presented at the annual meetings of the Academy of Management, Montreal, August 2010.

Glaeser, E., H. Kallal, J. Scheinkman, and A. Shleifer (1992), 'Growth of Cities,' Journal of Political Economy, 100(6), 1126-1152.

Golder, P.N. and G.J. Tellis (2004), 'Growing, Growing, Gone: Cascades, Diffusion, and Turning Points in the Product Life Cycle,’ Marketing Science, 23(2), 207-218.

Gorbachev, M. (1987), Perestroika: New Thinking for Our Country and the World. Harper \& Row: New York, NY.

Griliches, Z. (1979), 'Issues in Assessing the Contribution of R\&D to Productivity Growth,' Bell Journal of Economics, 10(1), 92-116.

Griliches, Z. (1998), R\&D and Productivity: the Econometric Evidence. University of Chicago Press: Chicago.

Hamel, G. (1991), 'Competition for Competence and Inter-partner Learning within International Strategic Alliances,’ Strategic Management Journal, 12(4), 83-103.

Hamilton, B.H. (2000), 'Does Entrepreneurship Pay? An Empirical Analysis of the Returns of SelfEmployment,' Journal of Political Economy, 108(3), 604-631.

Helpman, E. (ed.) (1998), General Purpose Technologies and Economic Growth. MIT Press: Cambridge, MA.

Henderson, R.M. and K.B. Clark (1990), 'Architectural Innovation: the Reconfiguration of Existing Product Technologies and the Failure of Established Firms,' Administrative Science Quarterly, 35(1), 9-30.

Hiebert, R.E. (2005), ‘Commentary: New Technologies, Public Relations, and Democracy,' Public Relations Review, 31(2), 1-9.

Ireland, R.D. and J.W. Webb (2007), 'Strategic Entrepreneurship: Creating Competitive Advantage through Streams of Innovation,’ Business Horizons, 50(1), 49-59. 
Jaffe, A., M. Trajtenberg, and R. Henderson (1993), 'Geographic Localization of Knowledge Spillovers as Evidenced by Patent Citations,' Quarterly Journal of Economics, 63(3), 577-598.

Jensen, M.C. (1993), 'The Modern Industrial Revolution, Exit, and the Failure of Internal Control Systems,' Journal of Finance, 48(July), 831-880.

Jovanovic, B. and P.L. Rousseau (2005), 'General Purpose Technologies,' in: Ph. Aghion and S. Durlauf (eds.), Handbook of Economic Growth. Elsevier: Amsterdam, 1181-1224.

Kedzie, Ch.R. (1997), Communication and Democracy: Coincident Revolutions and the Emergent Dictators. The F.S. Pardee RAND Graduate School dissertation series.

Klepper, S. (1996), 'Entry, Exit, Growth, and Innovation over the Product Life Cycle,' American Economic Review, 86(4), 562-583.

Knight, F.H. (1971), Risk, Uncertainty, and Profit. The University of Chicago Press: Chicago, originally published in 1921 by Houghton Mifflin Company.

Kotz, D. and F. Weir. (1997), Revolution from Above: The Demise of the Soviet System. Routledge: London.

Langlois, R.N. (2002), 'Modularity in Technology and Organization,' Journal of Economic Behavior and Organization, 49(1), 19-37.

Langlois, R.N. (2003), 'The Vanishing Hand: the Changing Dynamics of Industrial Capitalism,' Industrial and Corporate Change, 12(2), 351-385.

Lee, H.L. (2002), 'Aligning Supply Chain Strategies with Product Uncertainties,' California Management Review, 44(3), 105-119.

L'Huillery, S. (2006), 'Voluntary Technological Disclosure as an Efficient Knowledge Management Device: an Empirical Study,' Economics of Innovation and New Technology, 15(4-5), 465-491.

Liebeskind, J.P. (1996), 'Knowledge, Strategy, and the Theory of the Firm,' Strategic Management Journal, 17(winter special issue), 93-107.

Lucas, R. E. (1978), 'On the Size Distribution of Business Firms,' Bell Journal of Economics, 9(2), 508523.

Lucas, R.E. (1988), 'On the Mechanics of Economic Development,' Journal of Monetary Economics, 22(1), 3-42.

Lucas, R.E. (1993), ‘Making a Miracle,’ Econometrica, 61(2), 251-272.

March, J.G. (1991), 'Exploration and Exploitation in Organizational Learning,' Organization Science, 2(1), 71-87.

Marx, M., J. Singh and L. Fleming (2010), 'Regional Disadvantage? Non-Compete Agreements and Brain Drain,' unpublished paper presented at the annual meetings of the Academy of Management, Montreal, August 2010.

McLaren, J. (2000), 'Globalization' and Vertical Structure,' American Economic Review, 90(5), 12391254.

Milgrom, P. and J. Roberts (1990), 'The Economics of Modern Manufacturing: Technology, Strategy, and Organization,' American Economic Review, 80(3), 511-528.

Millan, J.M., J. Hessels, A.R. Thurik and R. Aguado (2011), Determinants of Job Satisfaction across the EU-15: a Comparison of Self-Employed and Paid Employees, Tinbergen Institute Discussion Paper, forthcoming.

Nachum, L. and S. Zaheer (2005), 'The Persistence of Distance? The Impact of Technology on MNE Investment Motivations,' Strategic Management Journal, 26(8), 747-768.

Nelson, R.R. (ed.) (1993), National Innovation Systems, A Comparative Analysis. Oxford University Press: New York.

Nooteboom, B. (1993), 'Firm Size Effects on Transaction Costs,' Small Business Economics, 5(4), 283295.

Nooteboom, B. (1994), 'Innovation and Diffusion in Small Firms: Theory and Evidence,' Small Business Economics, 6(5), 327-347.

Nooteboom, B. (1999), Interfirm Alliances: Analysis and Design. Routledge: London.

Nooteboom, B. (2000), Learning and Innovation in Organizations and Economies. Oxford University Press: Oxford.

Nooteboom, B. (2002), Trust Forms, Foundations, Functions, Failures and Figures. Edward Elgar: Cheltenham, UK, Northampton, Ma.

Nooteboom, B. and E. Stam (2008), Micro-Foundations for Innovation Policy. Amsterdam: Amsterdam University Press. 
OECD (2008), Main Economic Indicators. Organisation for Economic Co-operation and Development: Paris.

OECD (2009), OECD Economic Outlook No. 85, Organisation for Economic Co-operation and Development: Paris.

Oviatt, B.M. and P.Ph. McDougall (1994), ‘Toward a Theory of International New Ventures,' Journal of International Business Studies, 25(1), 45-64.

Parker, Ph.M. (1992), 'Price Elasticity Dynamics over the Adoption Life Cycle,' Journal of Marketing Research, 29(3), 358-367.

Penrose, E., J. George and P. Stevens (1992), 'Nationalisation of Foreign-Owned Property for a Public Purpose: An Economic Perspective on Appropriate Compensation,' Modern Law Review 55(3). 351367.

Piore, M. and C. Sabel (1984), The Second Industrial Divide. Basic Books: New York.

Pratten, C.F. (1971), Economies of Scale in Manufacturing Industry. Cambridge University Press: Cambridge.

Robinson, J. (1995), 'Technology, Change, and the Emerging International Order,' SAIS Review, 15(1), 153-173.

Romer, P.M. (1986), 'Increasing Returns and Long-run Growth,' Journal of Political Economy, 94(5), 1002-1037.

Romer, P.M. (1990), ‘Endogenous Technical Change,’ Journal of Political Economy, 98(5), S71-S102.

Sabel, Ch.F. and J. Zeitlin, (2004), 'Neither Modularity nor Relational Contracting: Inter-firm Collaboration in the New Economy,' Enterprise and Society, 5(3), 388-403.

Scherer, F.M. (1991), 'Changing Perspectives on the Firm Size Problem,' in Z.J. Acs and D. B. Audretsch, (eds.), Innovation and Technological Change: An International Comparison. Ann Arbor: University of Michigan Press, 24-38.

Servan-Schreiber, J.-J. (1968), The American Challenge. London: Hamish Hamilton.

Servan-Schreiber, J.-J. (1980), Le Défi Mondial. Paris: Fayard.

Shane, S. (1994), Dismantling Utopia: How Information Ended the Soviet Union. Chicago: Ivan R. Dee Publisher.

Shane, S., and S. Venkataraman (2000), 'The Promise of Entrepreneurship as a Field of Research,' Academy of Management Review, 25(1), 217-226.

Shapiro, C. and H.R. Varian, (1999), Information Rules: A Strategic Guide to the Network Economy. Harvard Business School Press: Boston, Ma.

Shultz, G.P. (1985), 'Shaping American Foreign Policy: New Realities and New Ways of Thinking,' Foreign Affairs, 63(4), 705-721.

Solow, R. (1956), 'A Contribution to the Theory of Economic Growth,' Quarterly Journal of Economics, 70(1), 65-94.

Stam, E. (2007), 'Why Butterflies Don't Leave. Locational behavior of entrepreneurial firms,' Economic Geography, 83(1), 27-50.

Stam, E. and B. Nooteboom (2011), Entrepreneurship, Innovation and Institutions. In: Audretsch, D., Falck, O. \& Heblich, S. (eds) Handbook of Research on Innovation and Entrepreneurship. Cheltenham: Edward Elgar, 421-438.

Stel, A.J. van, D. Storey and A.R. Thurik (2007), 'The Effect of Business Regulations on Nascent to Young Business Entrepreneurship,' Small Business Economics, 28(2-3), 171-186.

Teece, D.J. (1993), 'The Dynamics of Industrial Capitalism: Perspectives on Alfred Chandler's "Scale and Scope”,' Journal of Economic Literature, 31(1), 199-225.

Tirole, J. (1989), The Theory of Industrial Organization. MIT Press: Cambridge, Ma.

The Economist (2010), Global heroes: a special report on entrepreneurship, March 14.

Thurik, A.R., M.A. Carree, A. van Stel and D.B. Audretsch (2008), 'Does Self-Employment Reduce Unemployment?' Journal of Business Venturing, 23(6), 673-686.

Thurik, A.R. (2009), 'Entreprenomics: Entrepreneurship, Economic Growth and Policy,' in: Z.J. Acs, D.B. Audretsch and R. Strom (eds.), Entrepreneurship, Growth and Public Policy. Cambridge University Press: Cambridge, UK, 219-249.

Thurow, L.C. (2002), Fortune Favors the Bold: What We Must Do to Build a New and Lasting Global Prosperity. MIT Press: Cambridge, Ma. 
Tripsas, M. (1997), 'Unraveling the Process of Creative Destruction: Complementary Assets and Incumbent Survival in the Typesetter Industry,' Strategic Management Journal, 18(summer special issue), 119-142.

Uhlaner, L. and A. R. Thurik (2007), 'Postmaterialism influencing total entrepreneurial activity across nations,' Journal of Evolutionary Economics, 17(2), 161-185

UNCTAD (2004), World Investment Report 2004: The Shift towards Services. United Nation Conference on Trade and Development: New York and Geneva, available at: http://www.unctad.org/wir (June 2010).

UNCTAD (2007), World Investment Report 2007: Transnational Corporations, Extractive Industries and Development. United Nation Conference on Trade and Development: New York and Geneva, available at: http://www.unctad.org/wir (June 2010).

UNCTAD (2009), World Investment Report 2007: Transnational Corporations, Agricultural Production and Development. United Nation Conference on Trade and Development: New York and Geneva, available at: http://www.unctad.org/wir (June 2010).

Weiss, L.W. (1976), 'Optimal Plant Scale and the Extent of Suboptimal Capacity', in R.T. Masson and P.D. Qualls (eds.), Essays on Industrial Organization in the Honor of Joe S. Bain. Ballinger: Cambridge, MA, 126-134.

Wennekers, S., M. Carree, A. van Stel and R. Thurik (2010), 'The Relationship between Entrepreneurship and Economic Development: is it U-shaped?' Foundations and Trends in Entrepreneurship, 6(3), 167-237.

Wennekers, S., A. van Stel, R. Thurik and P. Reynolds (2005), 'Nascent Entrepreneurship and the Level of Economic Development,' Small Business Economics, 24(3), 293-309.

Zahra, S.A. and G. George, (2002), 'Absorptive Capacity: a Review, Reconceptualization and Extension,’ Academy of Management Review, 27(2), 185-203. 